\title{
Soil pH Effects on Growth and Foliar Nutrient Concentrations of Spiraea alba Du Roi and Spiraea tomentosa L.
}

\author{
Michael V. Mickelbart ${ }^{1}$ and Michael J. Gosney \\ Department of Horticulture and Landscape Architecture, Purdue University, \\ 625 Agriculture Mall Drive, West Lafayette, IN 47907
}

\section{James Camberato}

Department of Agronomy, Purdue University, 915 West State St., West Lafayette, IN 47907

\section{Kelly M. Stanton \\ Department of Horticulture and Landscape Architecture, Purdue University, 625 Agriculture Mall Drive, West Lafayette, IN 47907}

Additional index words. meadowsweet, steeplebush, hardhack, native plants

\begin{abstract}
The North American native plants Spiraea alba and S. tomentosa have potential as landscape plants because they are small- to medium-sized shrubs with showy flowers that persist from early to late summer. However, the cultural requirements of these species are not well documented. Both species grow in slightly acidic soils in their native habitats. The objective of this work was to determine if the growth and/or appearance of these shrubs is affected by the neutral to slightly alkaline soils common throughout the Midwest. Spiraea alba grown from three seed sources and $S$. tomentosa grown from a single seed source were grown for 2 years in soils of different $\mathrm{pH}$. Elemental sulfur (S) was incorporated into a Drummer silty clay loam with a $\mathrm{pH}$ of 7.2 to bring the $\mathrm{pH}$ to 5.8 and 6.42 years after incorporation, thus establishing plots with three pH levels for assessing growth and appearance. The soil pH increased to 6.4 and 6.8 in the amended plots between Years 2 and 3 after $S$ incorporation. Soil concentrations of exchangeable magnesium (Mg) and calcium (Ca) were lowered with added S. Height and width varied among $S$. alba from different seed sources, and height and width of all plants were reduced when grown at the highest soil $\mathrm{pH}$. Leaf greenness, specific leaf weight, and individual leaf area were unaffected by $\mathrm{pH}$. Leaf concentrations of nitrogen, potassium, zinc, and manganese were higher in lower soil $\mathrm{pH}$, whereas $\mathrm{Mg}$ was lowest at the lowest soil $\mathrm{pH}$. These results suggest that $S$. alba and $S$. tomentosa can be grown in neutral pH soils without an effect on plant appearance, but plant size will be less than at pH levels closer to the native soils for these species. Although some micronutrients were present at lower concentrations at the neutral $\mathrm{pH}$, leaf greenness was unaffected, again suggesting that these plants may perform suitably outside of their native habitat $\mathrm{pH}$ range.
\end{abstract}

The native shrubs Spiraea alba (meadowsweet) and S. tomentosa (hardhack or steeplebush) grow to be 1 to $1.5 \mathrm{~m}$ tall with long-lasting terminal inflorescences (white and pink flowers, respectively) present throughout most of the summer. Both species are native to the eastern United States and Canada and can be found growing from Canada to the Gulf states (U.S. Department of Agriculture, 2012). Spiraea tomentosa was used in the landscape as early as 1736 (Symes, 1983), but today both species

Received for publication 1 Feb. 2012. Accepted for publication 21 Mar. 2012.

We thank Wildtype Nursery, Possibility Place Nursery, and the National Plant Germplasm Service for supplying plants and seed. Rob Eddy and Daniel Hahn assisted with greenhouse plant growth and maintenance. Tristand Tucker, Nathan Linder, and Daniel Elias assisted with field setup, maintenance, and measurements.

${ }^{1}$ To whom reprint requests should be addressed; e-mailmickelbart@purdue.edu. and $S$. tomentosa are typically found in wet acidic soils (Braun, 1936; Koning, 2005; Meilleur et al., 1997). Spiraea tomentosa has been found in soils with a $\mathrm{pH}$ as low as 4 or as high as 7 but it is rare above $\mathrm{pH} 6$ (Baines, 1973; Gille, 1950), and S. alba is found in soils below pH 6 (Girardin et al., 2001; White, 1965).

There are a number of methods for decreasing the $\mathrm{pH}$ of field soils (Mickelbart et al., 2012). Elemental $\mathrm{S}$ has been successfully used to lower soil $\mathrm{pH}$ provided the carbonate levels in the soil are not too high (Camberato, 1999). We used elemental $\mathrm{S}$ to lower the $\mathrm{pH}$ of field soil with a $\mathrm{pH}$ of $\approx 7.2$. The objective of this study was to determine if $S$. alba and $S$. tomentosa growth and appearance are affected by soil $\mathrm{pH}$ higher than that found in their natural range. The growth, appearance, and leaf nutrient content of $S$. alba (grown from seed of three different geographical origins) and $S$. tomentosa (grown from seed of a single geographical origin) plants grown under several soil $\mathrm{pH}$ levels were evaluated to determine the landscape potential of these plants.

\section{Materials and Methods}

Field plots. The experiment was conducted at the Meigs Farm of the Throckmorton Purdue Agricultural Center in Tippecanoe County, IN (lat. $40.29^{\circ} \mathrm{N}$, long. $86.88^{\circ} \mathrm{W}$ ). The soil type is Drummer silty clay loam (fine-silty, mixed, superactive, mesic Typic Endoaquolls) with a $\mathrm{pH}$ of 7.2. Elemental S (90\% Pastille S; Agriliance LLC, St. Paul, MN) was incorporated in Apr. 2009 to a depth of $15 \mathrm{~cm}$ at rates of 0.27 and $0.11 \mathrm{~kg} \cdot \mathrm{m}^{-2} \mathrm{~S}$ to achieve target $\mathrm{pH}$ values of 6.0 and 6.5 , respectively. Plots with a target $\mathrm{pH}$ of 7.0 were not amended with $\mathrm{S}$. Plots were mulched with $\approx 8 \mathrm{~cm}$ pine bark. Weeds were manually removed and spotsprayed with glyphosate. The plots were irrigated with drip tape as required to avoid water stress. Plants were fertilized in April of 2010 and 2011 with $15 \mathrm{~g}$ of Scotts 33-3-6 (33\% N, $3 \% \mathrm{P}_{2} \mathrm{O}_{5}, 6 \% \mathrm{~K}_{2} \mathrm{O}$ ) field fertilizer derived from $0.6 \%$ ammoniacal nitrogen and $32.4 \%$ urea nitrogen (The Scotts Company LLC, Marysville, $\mathrm{OH})$.

Plant materials. Plants grown from three $S$. alba and one $S$. tomentosa seed sources were germinated and grown in $40-\mathrm{cm}^{3}$ plugs (Table 1). Plants were transplanted to 2 - $\mathrm{L}$ containers in Sept. 2008 and planted in the field on 31 Aug. 2009. All plants were pruned to $20 \mathrm{~cm}$ at planting. Each seed source was given a unique designation: the first letter indicates species and the next two letters are the postal code for the state or province of each seed source (Table 1). Two different Michigan accessions of S. alba (A-MI1 and A-MI2) were grown. Seed source A-MI1 was supplied from the National Plant Germplasm System Germplasm Resources Information Network (GRIN; accession number PI 564841) and seed source A-MI2 was supplied from Wildtype Nursery (Mason, MI). Possibility Place Nursery (Monee, IL) supplied seed of $S$. alba (A-IL) and S. tomentosa (T-IL), both collected from Will County, IL.

Measurements. Soil samples were collected before (Oct. 2008) and 1 (July 2010) 
and 2 (July 2011) years after S incorporation. Each time, a soil probe ( $2.5 \mathrm{~cm}$ diameter) was used to remove nine cores $15 \mathrm{~cm}$ deep from between plants in each plot. The top $1 \mathrm{~cm}$ was removed from each core to avoid contamination from vegetative material and the cores were combined, air-dried, and ground to pass a 2-mm sieve. Soil $\mathrm{pH}$ was determined in a 1:1 (soil:water) slurry (Watson and Brown, 1998). Soil phosphorus $(\mathrm{P}), \mathrm{Ca}$, potassium $(\mathrm{K})$, and $\mathrm{Mg}$ were extracted by the Mehlich 3 method (Mehlich, 1984) and measured with inductively coupled plasma atomic emission spectroscopy.

On 8 July 2011, plant height, plant width, and leaf greenness were determined and leaves were collected for measurements of leaf area (LA), specific leaf weight (SLW), and foliar nutrient concentrations. Plant height was determined as the vertical distance from the ground to the highest portion of the plant. The width of each plant was determined by averaging the north-south and east-west width. A SPAD 502 meter (Minolta, Osaka, Japan) was used to determine relative chlorophyll content of leaves (Netto et al., 2005). Measurements were made on three individual recently matured, fully expanded leaves and the mean of these measurements was recorded for each plant. Fifteen to 20 recently matured, fully expanded leaves were removed from each plant. The leaves were photographed and LA was determined from the photograph using Image J 1.38x (National Institutes of Health, Bethesda, MD). Leaves were then washed in reverse-osmosis water and dried to a constant weight at $70{ }^{\circ} \mathrm{C}$ to obtain leaf dry weight (DW). Specific leaf weight was calculated as $\mathrm{SLW}=\mathrm{DW} / \mathrm{LA}$. Leaves were ground to a fine powder using a coffee grinder. Nitrogen (N) was analyzed using the Dumas combustion procedure (Simonne et al., 1994). Leaf tissue was digested with $1 \mathrm{~mL}$ of $\mathrm{HNO}_{3}$ (Mallinckrodt, AR Select grade) at $110^{\circ} \mathrm{C}$ for $4 \mathrm{~h}$ and concentrations of all other elements were quantified by inductively coupled plasma spectrometry on a PerkinElmer Elan DRCe ICP-MS (PerkinElmer SCIEX, Shelton, CT).

Design and analysis. The three S. alba and one $S$. tomentosa ecotypes (Table 1) and three soil elemental $\mathrm{S}$ incorporation rates (main plots) were arranged in a split plot design on a randomized complete block with eight blocks and species/seed source randomized within each $\mathrm{S}$ incorporation plot. Each block contained three rates of $\mathrm{S}$ incorporation and each plot contained one plant of each ecotype. Each plot was $4.6 \mathrm{~m}$ long and $1.5 \mathrm{~m}$ wide and plots were separated by $2.7 \mathrm{~m}$ of buffer space between rows and $1.8 \mathrm{~m}$ between plots within a row. The data were analyzed using the PROC GLIMMIX procedure in SAS 9.1 (SAS Institute Inc., Cary, NC) with soil $\mathrm{pH}$ and seed source as fixed effects and block as a random effect. For soil measurements, soil $\mathrm{pH}$ and year were considered fixed effects and block as a random effect. Correlation analysis was performed with the PROC CORR procedure in SAS. Transformations of measured variables were used as needed to correct for variance and normality. The transformations used are given in the tables where the data are presented. All of the values presented are averages of the untransformed data.

\section{Results and Discussion}

Sulfur was used to decrease the soil $\mathrm{pH}$ of plots in which $S$. alba and $S$. tomentosa were grown to determine their adaptability to $\mathrm{pH}$ conditions. Incorporation of elemental $\mathrm{S}$ into soils results in a lowering of $\mathrm{pH}$ as a result of the oxidation of $\mathrm{S}$ to $\mathrm{H}_{2} \mathrm{~S}_{4}$ by microorganisms (Lindemann et al., 1991). Plots were amended in the spring of 2008, plants were planted in the plots in late Summer 2009, and soil characteristics were determined before amendments and 1 and 2 years after planting. Organic matter (OM) did not vary over years or among $\mathrm{pH}$ plots and the average $\mathrm{OM}$ overall plots and years was $3.8 \%$.

Incorporation of 0.27 and $0.11 \mathrm{~kg} \cdot \mathrm{m}^{-2}$ elemental $\mathrm{S}$ was effective in lowering the soil $\mathrm{pH}$ from an average value of 7.2 to 5.8 and 6.4, respectively, 22 months after incorporation (Fig. 1). However, 2 years after $\mathrm{S}$ incorporation, $\mathrm{pH}$ values had risen to 6.4 and 6.8 , respectively (Fig. 1). Throughout the experiment, the average soil $\mathrm{pH}$ of the three treatments were all significantly different from each other. Incorporation of elemental $\mathrm{S}$ is effective for reducing $\mathrm{pH}$ in many soils, but the reduction may be temporary (Janzen and Bettany, 1987) as was the case in our study (Fig. 1). Reaction of acidity generated with residual calcium carbonate may explain the increase in $\mathrm{pH}$ over time in our study.

Table 1. Seed sources of $S$. alba and S. tomentosa used in this study. ${ }^{\mathrm{z}}$

\begin{tabular}{llll}
\hline ID & \multicolumn{1}{c}{ Species } & \multicolumn{1}{c}{ Supplier } & Seed collection site \\
\hline A-IL & S. alba & Possibility Place Nursery & Will Co., IL \\
A-MI1 & S. alba & NPGS & Kent Co., MI \\
A-MI2 & S. alba & Wildtype Nursery & Jackson Co., MI \\
T-IL & S. tomentosa & Possibility Place Nursery & Will Co., IL \\
\hline
\end{tabular}

${ }^{2}$ The ID given to each seed source indicates species $(\mathrm{A}=S$. alba, $\mathrm{T}=S$. tomentos $a)$ and the postal code of the state of each source $(\mathrm{MI}=$ Michigan, $\mathrm{IL}=\mathrm{Illinois})$. Plants were supplied as seed from the National Plant Germplasm System (NPGS) or as plugs from two commercial nurseries (Possibility Place and Wildtype Nursery). State and county where seed was collected are indicated (seed collection site).

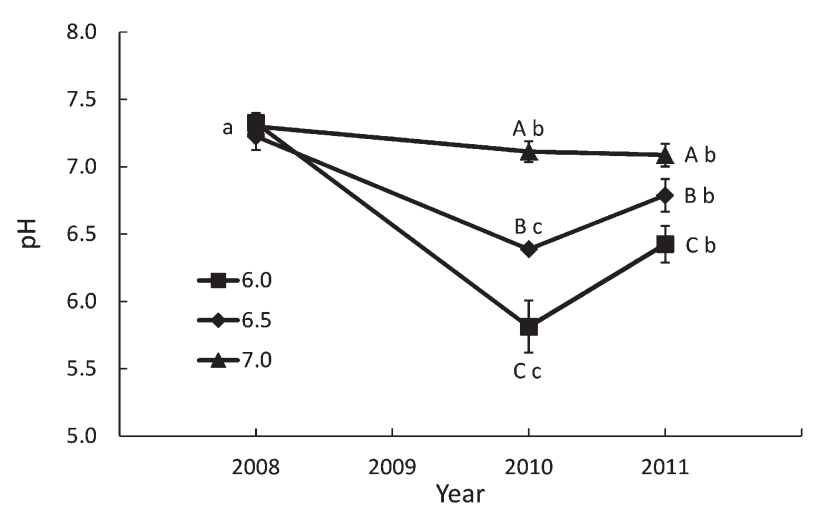

Fig. 1. Change in soil $\mathrm{pH}$ of three $\mathrm{pH}$ treatments over 3 years. Symbols represent the mean of eight plots (blocks) in each year. Bars are SE. Significant differences among treatments within a year are indicated above the data points for each year ( $\mathrm{NS}=$ nonsignificant; $* * * P \leq 0.001$ ). The year $\times$ treatment interaction was significant $(P \leq 0.001)$, indicating that soil $\mathrm{pH}$ changed over years. Symbols with the same upper case letter within a year and symbols with the same lower case letter within a $\mathrm{pH}$ treatment are not different based on Tukey's honestly significant difference test $(P \leq 0.05)$. Sulfur incorporation occurred in 2009 and soil samples were collected in Oct. 2008 (before treatment initiation), July 2010, and July 2011. Plants were transplanted into plots in 2009. 
cations with acidic cations ( $\mathrm{Al}$ and $\mathrm{H}$ ) (Darusman et al., 1991; Finn et al., 1993; McCoy and Webster, 1977; Schwab et al., 1989), although effects are not always detected (Peterson et al., 1987). Soil Ca also increased by $8.5 \%$ from 2010 to 2011, which may be the result of dissolution of residual calcium carbonate (U.S. Department of Agriculture, 1954). The value of soil $\mathrm{Mg}$ was $3 \%$ higher in 2011 than 2008, but there were no significant differences between the years.

Genotypic differences in growth response to soil or media $\mathrm{pH}$ have been documented in several woody species including Dirca palustris (Peterson and Graves, 2009), Vaccinium corymbosum (Austin and Bondari, 1992), and Acer rubrum (Boyce and Sydnor, 1983). The Illinois seed source of $S$. alba generally was shorter than the Michigan seed source plants (Table 2), similar to what was previously reported for these genotypes (Stanton et al., 2010a). All plants were larger when grown in lower $\mathrm{pH}$ soils (Table 3 ). There were no seed source $\times \mathrm{pH}$ effects, suggesting that genotype growth response to changes in soil $\mathrm{pH}$ was similar. However, because the number of genotypes used in this experiment was small, it is possible that variation in growth response to $\mathrm{pH}$ may exist in these species. Although overall growth was reduced when plants were grown at neutral $\mathrm{pH}$, individual leaf size was unaffected by soil $\mathrm{pH}$ in either species (Table 3 ), suggesting that lower annual shoot extension is the reason for reduced height and width.

Leaf chlorophyll concentration or greenness is often higher when acidic soil-adapted species are grown on slightly acidic as opposed to neutral soils (Anderson and Ladiges, 1978; Peterson and Graves, 2009). Spiraea tomentosa has thicker, darker green leaves than $S$. alba (Table 3; Stanton et al., 2010b), but soil $\mathrm{pH}$ did not affect either of these traits in either species (Table 3). Leaf greenness is sometimes correlated with leaf nutrient concentrations other than $\mathrm{N}$ such as Ca (Fernández-Falcón et al., 2006), but in this study, it was not correlated with any differences in foliar nutrient concentrations (data not shown) although concentrations of several nutrients were different at various soil $\mathrm{pH}$ levels (Table 4).

Overall, the Illinois seed source of $S$. alba had lower concentrations of $\mathrm{N}, \mathrm{P}, \mathrm{K}, \mathrm{S}, \mathrm{Mn}$,

Table 2. Main effect ( $\mathrm{pH}$ and year) values for the soil properties $\mathrm{pH}$ and nutrient concentrations. ${ }^{\mathrm{z}}$

\begin{tabular}{lcccc}
\hline & Phosphorus $\left(\mathrm{mg} \cdot \mathrm{kg}^{-1}\right)$ & Potassium $\left(\mathrm{mg} \cdot \mathrm{kg}^{-1}\right)$ & Magnesium $\left(\mathrm{mg} \cdot \mathrm{kg}^{-1}\right)$ & Calcium $\left(\mathrm{mg}^{\circ} \mathrm{kg}^{-1}\right)$ \\
\hline $\mathrm{pH}(\mathrm{P})^{\mathrm{y}}$ & NS & NS & $*$ & $* *$ \\
Year $(\mathrm{Y})$ & $* * *$ & $* * *$ & NS & $* * *$ \\
$\mathrm{P} \times \mathrm{Y}$ & NS & NS & NS & NS \\
$\mathrm{pH}$ & & 107 & $387 \mathrm{~b}$ & $2200 \mathrm{~b}$ \\
6.0 & 30 & 111 & $398 \mathrm{ab}$ & $2260 \mathrm{ab}$ \\
6.5 & 31 & 107 & $414 \mathrm{a}$ & $2335 \mathrm{a}$ \\
7.0 & 30 & & & \\
Year & & $93 \mathrm{c}^{\mathrm{x}}$ & 392 & $2229 \mathrm{~b}$ \\
2008 & $25 \mathrm{~b}$ & $105 \mathrm{~b}$ & 404 & $2190 \mathrm{~b}$ \\
2010 & $32 \mathrm{a}$ & $126 \mathrm{a}$ & 403 & $2377 \mathrm{a}$ \\
2011 & $33 \mathrm{a}$ & &
\end{tabular}

${ }^{\mathrm{z}}$ Elemental sulfur was added to plots to obtain soil $\mathrm{pH}$ levels of 6.0,6.5, and 7.0. Sulfur incorporation occurred in 2009 and soil samples were collected in Oct. 2008 (before treatment initiation), July 2010, and July 2011. Plants were transplanted into plots in 2009. Means are of 24 soil samples: eight blocks and 3 years for $\mathrm{pH}$ main effects; eight blocks and three $\mathrm{pH}$ levels for year main effects.

$\mathrm{y}_{\mathrm{NS}}, *, * *$, or $* * *$ Nonsignificant or significant at $P \leq 0.05,0.01$, or 0.001 , respectively.

${ }^{x}$ Means within each column followed by the same letter are not different at $P \leq 0.05$ based on Tukey's honestly different significance test.

Table 3. Main effect (pH and year) values for plant growth (height and width) and leaf greenness (SPAD), specific leaf weight (SLW), and individual leaf area (LA). ${ }^{\mathrm{z}}$

\begin{tabular}{|c|c|c|c|c|c|}
\hline & $\mathrm{Ht}(\mathrm{cm})$ & Width $(\mathrm{cm})$ & SPAD & $\mathrm{SLW}\left(\mathrm{mg} \cdot \mathrm{cm}^{-2}\right)$ & LA $\left(\mathrm{cm}^{-2}\right)$ \\
\hline$\overline{\mathrm{pH}(\mathrm{P})^{\mathrm{y}}}$ & $* * *$ & $* * *$ & NS & NS & NS \\
\hline Seed source $(\mathrm{S})$ & $* * *$ & $* * *$ & $* * *$ & $* * *$ & $* * *$ \\
\hline $\mathrm{P} \times \mathrm{S}$ & NS & NS & NS & NS & NS \\
\hline \multicolumn{6}{|l|}{$\mathrm{pH}$} \\
\hline 6.0 & $88.0 \mathrm{a}^{\mathrm{x}}$ & $61.0 \mathrm{a}$ & 34.6 & 7.07 & 4.39 \\
\hline 6.5 & $87.3 \mathrm{a}$ & $51.5 \mathrm{a}$ & 35.6 & 7.42 & 4.02 \\
\hline 7.0 & $74.0 \mathrm{~b}$ & $39.9 \mathrm{~b}$ & 33.9 & 7.37 & 3.60 \\
\hline \multicolumn{6}{|l|}{ Seed source } \\
\hline A-IL & $66.4 \mathrm{c}$ & $59.3 \mathrm{a}$ & $31.5 \mathrm{~b}$ & $7.58 \mathrm{~b}$ & $3.96 \mathrm{ab}$ \\
\hline A-MI1 & $94.1 \mathrm{~b}$ & $43.9 \mathrm{~b}$ & $32.6 \mathrm{~b}$ & $6.16 \mathrm{~d}$ & $3.32 \mathrm{~b}$ \\
\hline A-MI2 & $110.7 \mathrm{a}$ & $62.8 \mathrm{a}$ & $33.5 \mathrm{~b}$ & $6.76 \mathrm{c}$ & $4.02 \mathrm{ab}$ \\
\hline T-IL & $61.2 \mathrm{c}$ & $37.2 \mathrm{~b}$ & $41.1 \mathrm{a}$ & $8.66 \mathrm{a}$ & $4.72 \mathrm{a}$ \\
\hline
\end{tabular}

${ }^{\mathrm{z} E l e m e n t a l}$ sulfur was added to plots to obtain soil $\mathrm{pH}$ levels of 6.0, 6.5, and 7.0. Sulfur incorporation occurred in 2009 and soil samples were collected in Oct. 2008 (before treatment initiation), July 2010, and July 2011. Plants were transplanted into plots in 2009. Values are the averages of eight blocks and four seed sources $(\mathrm{n}=32)$ for $\mathrm{pH}$ or eight blocks and three $\mathrm{pH}$ levels $(\mathrm{n}=24)$ for seed source main effect.

$\mathrm{y}_{\mathrm{NS}}, * * *$, or $* * *$ Nonsignificant or significant at $P \leq 0.05,0.01$, or 0.001 , respectively.

${ }^{\mathrm{x}}$ Means within each column followed by the same letter are not different at $P \leq 0.05$ based on Tukey's honestly different significance test. and $\mathrm{Cu}$ than the other S. alba ecotypes (Table 4). Foliar $\mathrm{N}$ concentrations are often higher at soil or media $\mathrm{pH}$ below 7.0 in a wide range of species (Peterson et al., 1987; Silber et al., 2000; Smith et al., 2004), and this was true in this experiment (Table 4). Foliar P varied among species and accessions but was unaffected by soil $\mathrm{pH}$, whereas foliar $\mathrm{K}$ was slightly lower in plants growing in amended soils (Table 4), although neither $\mathrm{P}$ nor $\mathrm{K}$ was apparently more available in the amended soils (Table 2). Despite differences in soil $\mathrm{Ca}$ concentrations (Table 2), foliar $\mathrm{Ca}$ was not different in plants growing at different $\mathrm{pH}$ levels (Table 4). Furthermore, there was no genetic variation for foliar $\mathrm{Ca}$ (Table 3). Soil $\mathrm{Mg}$ was only slightly higher in amended soils (Table 2) and this was reflected in slightly higher foliar $\mathrm{Mg}$ concentrations (Table 4). Although soil-available $\mathrm{S}$ was not measured, it is likely that S was available at higher concentrations to plants growing in the amended soils (Lindemann et al., 1991). However, sulfate derived from incorporation of elemental $\mathrm{S}$ may be depleted quickly after application as a result of leaching or immobilization (Janzen and Bettany, 1987). This may account for the fact that foliar $\mathrm{S}$ was not higher in any plants grown in amended soils (Table 4).

The micronutrients $\mathrm{Fe}, \mathrm{Mn}$, and $\mathrm{Cu}$ were all present in higher concentrations in leaves of plants growing in the S-amended soils (Table 4). This was most dramatic for leaf $\mathrm{Mn}$ concentrations: foliar $\mathrm{Mn}$ concentrations at soil $\mathrm{pH}$ of 6.5 and 7.0 were $41 \%$ and $14 \%$ that of Mn concentrations at $\mathrm{pH}$ 6.0. Foliar Mn concentrations often decline with increases in soil $\mathrm{pH}$ in plants adapted to acidic soils such as blueberry (Finn et al., 1993; Peterson and Graves, 2009). There were no $\mathrm{pH} \times$ seed source interactions for leaf nutrient concentrations except for $\mathrm{Zn}$ (Fig. 2), indicating that all genotypes responded similarly to changes in soil pH. Foliar $\mathrm{Zn}$ concentrations declined with an increase in $\mathrm{pH}$ in A-IL and T-IL, but not in the Michigan $S$. alba seed sources (Fig. 2). We did not measure soil Zn, but $\mathrm{S}$ incorporation to reduce soil $\mathrm{pH}$ can result in increased $\mathrm{Zn}$ availability (Wang et al., 2006). If $\mathrm{Zn}$ was more available at lower soil $\mathrm{pH}$, the A-MI2 genotype did not respond to this increase with higher foliar $\mathrm{Zn}$ concentrations as the other genotypes did (Fig. 2). There were no symptoms that suggested higher concentrations of $\mathrm{Zn}, \mathrm{Mn}$, or $\mathrm{Cu}$ at lower soil $\mathrm{pH}$ were toxic. Soil $\mathrm{pH}$ also did not affect the foliar concentrations of $\mathrm{Fe}, \mathrm{Cu}$, boron, or $\mathrm{Al}$ (Table 4).

In conclusion, plants of $S$. alba and $S$. tomentosa were generally smaller and had lower foliar concentrations of some nutrients when grown in the neutral $\mathrm{pH}$ soil of the experimental field site. However, leaf size and greenness did not differ with soil $\mathrm{pH}$. Taken together, this suggests that these species can be grown in more neutral landscape soils typical of many parts of the Midwest. However, they may benefit from some reduction in soil $\mathrm{pH}$ either through incorporation of sulfur or organic material or by the use of acidic fertilizers. 
Table 4. Leaf nutrient concentrations of Spiraea alba (A-IL, A-MI1, and A-MI2) and Spiraea tomentosa after 2 years growing in field soils of pH 6.0, 6.5, or 7.0. ${ }^{\text {. }}$

\begin{tabular}{|c|c|c|c|c|c|c|c|c|c|c|c|}
\hline & Nitrogen & Phosphorus & Potassium & Calcium & Magnesium & Sulfur & Manganese $^{\mathrm{y}}$ & Iron & Copper & Boron & Aluminum \\
\hline & \multicolumn{6}{|c|}{$\left(\mathrm{mg} \cdot \mathrm{g}^{-1}\right)$} & \multicolumn{5}{|c|}{$\left(\mu \mathrm{g} \cdot \mathrm{g}^{-1}\right)$} \\
\hline Seed source $(\mathrm{S})$ & $* * *$ & *** & $* * *$ & NS & NS & $* * *$ & $* *$ & $* * *$ & $* * *$ & $* * *$ & $* * *$ \\
\hline 6.0 & $2.05 \mathrm{a}^{\mathrm{w}}$ & 0.41 & $1.03 \mathrm{a}$ & 0.93 & $0.15 \mathrm{~b}$ & 0.15 & $364 \mathrm{a}$ & 72 & 7.3 & 23 & 29 \\
\hline 6.5 & $1.95 \mathrm{ab}$ & 0.46 & $1.03 \mathrm{a}$ & 0.91 & $0.17 \mathrm{ab}$ & 0.15 & $150 \mathrm{~b}$ & 68 & 7.2 & 24 & 25 \\
\hline 7.0 & $1.89 \mathrm{~b}$ & 0.41 & $0.92 \mathrm{~b}$ & 0.91 & $0.19 \mathrm{a}$ & 0.14 & $51 \mathrm{c}$ & 66 & 6.6 & 22 & 30 \\
\hline A-MI1 & $2.14 \mathrm{a}$ & $0.46 \mathrm{ab}$ & $1.13 \mathrm{a}$ & 0.93 & 0.17 & $0.16 \mathrm{a}$ & $211 \mathrm{a}$ & $63 \mathrm{ab}$ & $7.3 \mathrm{~b}$ & $25 \mathrm{a}$ & $22 \mathrm{~b}$ \\
\hline A-MI2 & $2.12 \mathrm{a}$ & $0.51 \mathrm{a}$ & $1.08 \mathrm{a}$ & 0.93 & 0.18 & $0.16 \mathrm{a}$ & $207 \mathrm{a}$ & $73 \mathrm{a}$ & $7.0 \mathrm{~b}$ & $25 \mathrm{a}$ & $29 \mathrm{ab}$ \\
\hline T-IL & $1.82 \mathrm{~b}$ & $0.42 \mathrm{~b}$ & $0.83 \mathrm{~b}$ & 0.87 & 0.16 & $0.13 \mathrm{~b}$ & $204 \mathrm{ab}$ & $76 \mathrm{a}$ & $8.5 \mathrm{a}$ & $18 \mathrm{~b}$ & $37 \mathrm{a}$ \\
\hline
\end{tabular}

${ }^{2}$ Elemental sulfur was added to plots in spring of 2009 to obtain soil pH levels of 6.0, 6.5, and 7.0, plants were transplanted into plots in 2009, and leaves were sampled in July 2011. Values are the averages of eight blocks and four seed sources $(\mathrm{n}=32)$ for $\mathrm{pH}$ or eight blocks and three $\mathrm{pH}$ levels $(\mathrm{n}=24)$ for seed source main effect.

${ }^{\mathrm{y}} \mathrm{Log}$ values were analyzed to correct for non-normal distribution of data.

${ }^{\mathrm{NS}}, *, * *$, or $* * *$ Nonsignificant or significant at $P \leq 0.05,0.01$, or 0.001 , respectively.

w'Means within each column followed by the same letter are not different at $P \leq 0.05$ based on Tukey's honestly different significance test.

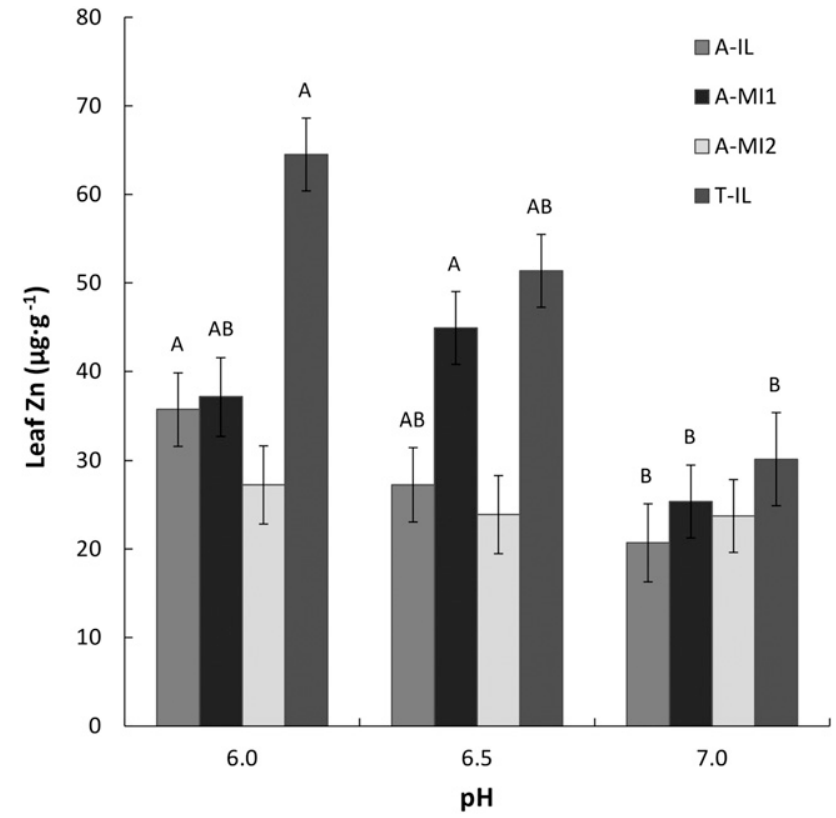

Fig. 2. Foliar zinc (Zn) concentration of Spiraea alba (A-IL, A-MI1, and A-MI2) and S. tomentosa (T-IL) plants in July after 2 years growth in soils with $\mathrm{pH}$ levels of 6.0, 6.5, or 7.0. Sulfur incorporation occurred in Spring 2009 and soil samples were collected in Oct. 2008 (before treatment initiation), July 2010, and July 2011. Plants were transplanted into plots in 2009. Columns are the means of eight blocks and bars represent SEM.

\section{Literature Cited}

Anderson, C.A. and P.Y. Ladiges. 1978. A comparison of three populations of Eucalyptus obliqua L'Herit growing on acid and calcareous soils in southern Victoria. Aust. J. Bot. 26:93-109.

Austin, M.E. and K. Bondari. 1992. Soil pH effects on yield and fruit size of two rabbiteye blueberry cultivars. J. Hort. Sci. Biotechnol. 67:779-786.

Baines, G.B.K. 1973. Plant distributions on a Saskatchewan prairie. Vegetatio 28:99-123 [now called Plant Ecology].

Boyce, E.A. and T.D. Sydnor. 1983. Effect of varying levels of manganese and $\mathrm{pH}$ on the growth of three cultivars of Acer rubrum. J. Arboric. 9:233-236.

Braun, L.E. 1936. Forests of the Illinoian till plain of southwestern Ohio. Ecol. Monogr. 6:89-149.

Camberato, J.J. 1999. Lowering soil pH with elemental sulfur. Carolinas Green, May-June 35(3):41.
Craul, P.J. and C.J. Klein. 1980. Characterization of streetside soils of Syracuse, New York. Metropolitan Tree Improvement Alliance Proc. 3:88-101.

Darusman, L., R. Stone, D.A. Whitney, K.A. Janssen, and J.H. Long. 1991. Soil properties after twenty years of fertilization with different nitrogen sources. Soil Sci. Soc. Amer. J. 55:1097-1100.

Fernández, F.G., S.M. Brouder, C.A. Beyrouty, J.J. Volenec, and R. Hoyum. 2008. Assessment of plant-available potassium for no-till, rainfed soybean. Soil Sci. Soc. Amer. J. 72:1085-1095.

Fernández-Falcón, M., M. Hernández, C.E. Alvarez, and A.A. Borges. 2006. Variation in nutrition along time and relative chlorophyll content of Leucospermum cordifolium cv. 'High Gold', and their relationship with chlorotic symptoms. Sci. Hort. 107:373-379.

Fielder, A.K. and D.A. Landis. 2007. Attractiveness of Michigan native plants to arthropod natural enemies and herbivores. Environ. Entomol. 36:751-765.
Finn, C.E., C.J. Rosen, J.J. Luby, and P.D. Ascher. 1993. Blueberry germplasm screening at several soil $\mathrm{pH}$ regimes. II. Plant nutrient composition. J. Amer. Soc. Hort. Sci. 118:383-387.

Gille, A. 1950. Le Spiraea tomentosa L. dans la region de Granby (Comté de Shefford, Québec, Canada): Étude écologique et phytosociologique. Vegetatio 2:166-196 [now called Plant Ecology].

Girardin, M., J. Tardif, and Y. Bergeron. 2001. Gradient analysis of Larix laricina dominated wetlands in Canada's southeastern boreal forest. Can. J. Bot. 79:444-456.

Janzen, H.H. and J.R. Bettany. 1987. Oxidation of elemental sulfur under field conditions in central Saskatchewan. Can. J. Soil Sci. 67:609-618.

Koning, C.O. 2005. Vegetation patterns resulting from spatial and temporal variability in hydrology, soils, and trampling in an isolated basin marsh, New Hampshire, USA. Wetlands 25:239-251.

Lehmann, A. and K. Stahr. 2007. Nature and significance of anthropogenic urban soils. J. Soils Sediments 7:247-260.

Lindemann, W.C., J.J. Aburto, W.M. Hafther, and A.A. Bono. 1991. Effect of sulfur source on sulfur oxidation. Soil Sci. Soc. Amer. J. 55:85-90.

Mallarino, A.P., M.W. Clover, and R.R. Oltmans. 2011. Identification of reasons for high temporal soil-test potassium variation. In: North-Central Extension-Industry Soil Fertility Conf. Proc. 16-17 Nov. Vol. 27. Des Moines, IA. p. 65-73.

McCoy, D.A. and G.R. Webster. 1977. Acidification of a Luvisolic soil caused by low-rate, long-term applications of fertilizers and its effects on growth of alfalfa. Can. J. Soil Sci. 57:119-121.

Mehlich, A. 1984. Mehlich 3 soil test extractant: A modification of Mehlich 2. Commun. Soil Sci. Plant Anal. 15:1409-1416.

Meilleur, A., H. Veronneau, and A. Bouchard. 1997. Shrub propagation techniques for biological control of invading tree species. Environ. Mgt. 21:433-442.

Mickelbart, M.V., J. Camberato, S. Hawkins, and K. Stanton. 2012. Lowering soil pH. Purdue Extension Publication H0-241-W.

Mikkelsen, R.L. and J.J. Camberato. 1995. Potassium, sulfur, lime, and micronutrient fertilizers, p. 109-138. In: Rechcigl, J.E. (ed.). Soil amendments and environmental quality. CRC Press, Boca Raton, FL.

Murdock, L. and D. Call. 2006. Managing seasonal fluctuations of soil tests. Univ. Kentucky Coop. Ext. Serv. AGR-189.

Netto, A.T., E. Campostrini, J.G. de Oliveira, and R.E. Bressan-Smith. 2005. Photosynthetic pigments, nitrogen, chlorophyll a fluorescence and 
SPAD-502 readings in coffee leaves. Sci. Hort. 104:199-209.

Oltmans, R.R. and A.P. Mallarino. 2011. Phosphorus and potassium removal and leaching from residue in corn and soybean. In: North-Central ExtensionIndustry Soil Fertility Conf. Proc. 16-17 Nov. Vol. 27. Des Moines, IA. p. 197-202.

Peterson, B.J. and W.R. Graves. 2009. Variation in development and response to root-zone $\mathrm{pH}$ among Dirca palustris (Thymelaeceae) from three different provenances. HortScience 44: 1319-1322.

Peterson, D.V., C.A. Mullins, D.A. Lietzke, and D.E. Deyton. 1987. Effects of soil-applied elemental sulfur, aluminum sulfate, and sawdust on growth of rabbiteye blueberries. J. Amer. Soc. Hort. Sci. 112:612-616.

Schwab, A.P., M.D. Ransom, and C.E. Owensby. 1989. Exchange properties of an Argiustoll: Effects of long-term ammonium nitrate fertilization. Soil Sci. Soc. Amer. J. 53:14121417.

Silber, A., A. Ackerman, B. Mitchnick, R. GanmoreNeumann, and J. Ben-Jaacov. 2000. pH dominates Leucadendron 'Safari Sunset'; growth. HortScience 35:647-650.

Simonne, E.H., H.A. Mills, J.B. Jones, D.A. Smittle, and G.G. Hussey. 1994. A comparison of analytical methods for nitrogen analysis in plant tissues. Commun. Soil Sci. Plant Anal. 25:943-954.

Smith, B.R., P.R. Fisher, and W.R. Argo. 2004. Nutrient uptake in container-grown impatiens and petunia in response to root substrate $\mathrm{pH}$ and applied micronutrient concentration. HortScience 39:1426-1431.

Sparks, D.L. 2012. Bioavailability of soil potassium, p. 11-37-11-61. In: Huang, et al. (eds.). Handbook of soil sciences: Resource management and environmental impacts. 2nd Ed. CRC Press, Boca Raton, FL.

Stanton, K.M., S.S. Weeks, M.N. Dana, and M.V. Mickelbart. 2010a. Pruning of meadowsweet and steeplebush. HortTechnology 20:700704.

Stanton, K.M., S.S. Weeks, M.N. Dana, and M.V. Mickelbart. 2010b. Light exposure and shade effects on growth, flowering, and leaf morphology of Spiraea alba Du Roi and Spiraea tomentosa L. HortScience 45:1912-1916.

Symes, M. 1983. Charles Hamilton's plantings at Painshill. Gard. Hist. 11:112-124.

Symonds, W.L., L.C. Campbell, and J. Clemens. 2001. Response of ornamental Eucalyptus from acidic and alkaline habitats to potting medium pH. Sci. Hort. 88:121-131.
Thomas, M.D. 1955. Effects of ecological factors on photosynthesis. Annu. Rev. Plant Physiol. 6:135-156.

Tinus, R.W. 1980. Nature and management of soil $\mathrm{pH}$ and salinity. Proc. North Amer. Forest Tree Nursery Soils Workshop, 28 July to Aug. 1980. 1:72-86.

U.S. Department of Agriculture. 1954. Improvement and management of soils in arid and semiarid regions in relation to salinity and alkali, p. 34-54. In: Richards, L.A. (ed.). Diagnosis and improvement of saline and alkali soils. U.S. Dept. of Agriculture, Washington, DC. Handbk. 60

U.S. Department of Agriculture. 2012. Spiraea L. The PLANTS database. National Plant Data Center, Baton Rouge, LA. 31 Jan. 2012. <http:// plants.usda.gov/java/profile?symbol=SPIRA $>$.

Wang, A.S., J.S. Angle, R.L. Chaney, T.A. Delorme, and R.D. Reeves. 2006. Soil pH effects on uptake of $\mathrm{Cd}$ and $\mathrm{Zn}$ by Thlaspi caerulescens. Plant Soil 281:325-337.

Watson, M.E. and J.R. Brown. 1998. Recommended chemical soil test procedures for the north central region, p. 13-16. NCR Research Publication No. 221. In: Brown, J.R. (ed.). University of Missouri, Columbia, MO.

White, K.L. 1965. Shrub-carrs of southeastern Wisconsin. Ecology 46:286-304. 